\title{
Consumption of Bats (Myotis spp.) by Raccoons (Procyon lotor) During an Outbreak of White-Nose Syndrome in New Brunswick, Canada: Implications for Estimates of Bat Mortality
}

\author{
Donald F. McAlpine ${ }^{1,2,3}$, Karen J. VAnderwolf ${ }^{1,2}$, Graham J. Forbes $^{2}$, and David Malloch ${ }^{1}$ \\ ${ }^{1}$ New Brunswick Museum, 277 Douglas Avenue, Saint John, New Brunswick E2K 1E5 Canada \\ ${ }^{2}$ Department of Biology, University of New Brunswick, Fredericton, New Brunswick E3B 6E1 Canada \\ ${ }^{3}$ Corresponding author (email: donald.mcalpine@nbm-mnb.ca)
}

McAlpine, Donald F., Karen J. Vanderwolf, Graham J. Forbes, and David Malloch. 2011. Consumption of bats (Myotis spp.) by Raccoons (Procyon lotor) during an outbreak of white-nose syndrome in New Brunswick, Canada: implications for estimates of bat mortality. Canadian Field-Naturalist 125(3): 257-260.

Across their range, Raccoons (Procyon lotor) will opportunistically exploit bats (Chiroptera) roosting in caves as a source of food. During a significant mortality event associated with white-nose syndrome (WNS) at a cave in eastern Canada, we estimate that Raccoons consumed 3169-3827 dead and dying Little Brown Bats (Myotis lucifugus) and Northern Long-eared Bats (M. septentrionalis) infected with white-nose syndrome, equivalent to $62.0-74.9 \%$ of the total bat mortality at this site. However, the generally small dispersal distances of Raccoons and their reduced activity during the period when bats are hibernating suggest that Raccoons are likely not a significant vector for moving the fungus associated with white-nose syndrome, Geomyces destructans, between most caves at this latitude. Nevertheless, since we show that significant numbers of bats can be consumed in hibernacula through opportunistic feeding by Raccoons, estimates of in-cave mortality due to white-nose syndrome should incorporate any evidence of consumption of bats by Raccoons and other predators.

Key Words: Geomyces destructans, Myotis lucifugus, Little Brown Bat, Myotis septentrionalis, Northern Long-eared Bat, Vespertilionidae, predation, Procyon lotor, Raccoon, scavenging, white-nose syndrome, New Brunswick, Canada.

White-nose syndrome (WNS) is a disease of hibernating vespertilionid bats first identified at Howes Cave, Albany, New York, in 2006 (Blehert et al. 2009). Since then, the U.S. Fish and Wildlife Service has estimated that 5.7-6.7 million North American cavernicolous bats have died following infection with the causative agent, the recently described ascomycete, Geomyces destructans (Lorch et al. 2011). Geomyces destructans is a slow-growing, psychrophilic (cold-adapted) fungus particularly well adapted to the cool, humid conditions characteristic of bat hibernacula. The disease has been described as the first sustained epizootic affecting bats in recorded history, with deaths far exceeding the rate and magnitude of any previously known natural or anthropogenic mortality event in bats (Cryan et al. 2010). The disease has spread rapidly from its apparent epicentre at a single cave and as of December 2011 has been confirmed in 17 U.S. states and 4 Canadian provinces.

Currently, the means of transmission and spread of Geomyces destructans are unknown (Foley et al. 2011). Although bat-to-bat contact appears to be the most likely means of routine dispersal (Lorch et al. 2011), ectoparasites have also been suggested (Foley et al. 2011). Wildlife managers currently have few strategies for controlling WNS that might reduce mortality (Foley et al. 2011). Nevertheless, in an effort to slow the spread of the disease, the U.S. Fish and Wildlife Service and state agencies have closed caves on public lands to recreational caving, and a detailed biosecurity protocol for those entering caves is now recommended
(U.S. Fish and Wildlife 2011*). In New Brunswick, the Department of Natural Resources is asking people to avoid entering caves and abandoned mines that are known overwintering sites for bats (New Brunswick $2011 *)$.

Here we examine the implications of opportunistic predation and scavenging by Raccoons on dying and dead bats (Myotis spp.) for estimates of mortality due to WNS. We also comment on the possibility that bat mortality coupled with opportunistic feeding by Raccoons (and other mammals) on bats infected with WNS could play a role in cave-to-cave transmission of Geomyces destructans.

\section{Methods}

WNS was first confirmed on hibernating vespertilionid bats (Myotis lucifugus and M. septentrionalis) in New Brunswick (Canada) at Berryton Cave $\left(45^{\prime} 52.524^{\circ} \mathrm{N}, 64^{\prime} 52.271^{\circ} \mathrm{W}\right)$, south of Moncton, on 15 March 2011. We made multiple visits to the site (six visits between October 2010 and June 2011). During our first encounter with bats with WNS (15 March 2011), we estimated mortality at $20 \%$ among the 6084 bats present in the hibernaculum. On the third and fourth visits (20 and 21 April 2011), with bat mortality estimated at $83 \%$, we noted large quantities of Raccoon (Procyon lotor) fæces at several sites starting at the cave entrance and extending to $150 \mathrm{~m}$ into the cave, which is $300 \mathrm{~m}$ long (Arsenault et al. 1997). Most of the fæces were concentrated within $50 \mathrm{~m}$ of the entrance in latrines, with scat of uniform diameter and blunt- 
ended, features typical for Racoon. The state of the fæces (some fresh, some frozen into ice in the front of the cave) and the overgrowth of fungi suggested one or more animals had been resident in the cave or had visited on multiple occasions over the previous month. Tracks evident on the cave floor suggested much recent Raccoon activity at the site (Figure 1). On 21 April we collected $3100.3 \mathrm{~g}$ of Raccoon fæces. On 10 June, with only a small amount of ice still present in the cave, we removed a further $1266.9 \mathrm{~g}$ of Raccoon fæces from the cave.

Pure cultures of $G$. destructans from samples collected from the Berryton Cave were established on modified (without oxgall and sodium propionate) dextrosepeptone-yeast extract (DPYA) agar (Papavizas and Davey 1958) and incubated at $7^{\circ} \mathrm{C}$ in a low-temperature incubator. About $8 \mathrm{~g}$ of Raccoon fæces collected from the cave were sterilized in an autoclave and inoculated from lab cultures with $G$. destructans and tracked to observe growth and sporulation.

Samples of Raccoon fæces collected from the cave were macerated in water under a dissecting microscope and examined for content. All fæces collected were then washed through a $36-\mathrm{mesh} / \mathrm{cm}^{2}$ sieve (No. 40 USA Standard Test Sieve), oven-dried $\left(\sim 60^{\circ} \mathrm{C}\right)$, and weighed to the nearest $0.1 \mathrm{~g}$, after the method of Greenwood (1979).

We used the wet weight digestibility coefficients presented by Greenwood (1979) for small mammals (based on Peromyscus sp. and Microtus sp.) and a songbird (Agelaius phoeniceus) to convert the dry weight of faecal residue to estimated total wet weight $(\mathrm{g})$ of bat tissue consumed. Using this conversion, we estimated the actual number of bats consumed, based on a mean body weight of $5.7 \mathrm{~g}(\mathrm{SD} \pm 0.82)$, derived from a sample of 366 Myotis lucifigus/M. septentrionalis collected from the floor of Berryton Cave on 17 March 2011.

\section{Results}

We examined collected faecal samples under a dissecting microscope and found them to be composed entirely of Myotis spp. hair, bone, fragments of wing, and tail membrane. Rarely was a near-intact or only partially digested bat found in the fæces. Some fæces were moist and appeared fresh, some were dry and dehydrated, and others supported extensive fungal growth (mostly Mucor sp. and Mortierella sp.). Geomyces destructans grew readily on autoclaved samples of Raccoon fæces, sporulating at $7^{\circ} \mathrm{C}$ in $<21$ days.

Greenwood (1979) found food residues (i.e., fæces) were usually expelled by Raccoons within two days. Although phalanges and radii-ulnæ were common in fæcal remains (demonstrating that bat wings were consumed), we also observed many wings scattered on the cave floor, indicated that a scavenger was sometimes preferentially eating the bodies and leaving the wings. Table 1 provides the results of converting wet weight of fæcal material collected in Berryton Cave to bat numbers and suggests that Raccoons consumed 31693827 individual Myotis spp., or an estimated 62.0$74.9 \%$ of the calculated total bat mortality for Berryton Cave in 2011.

\section{Discussion}

Across their range, Raccoons will opportunistically exploit bats as a source of food at cave sites. Winkler and Adams (1972) found Raccoons the most frequent, among several predatory mammals, utilizing Brazilian Free-tailed Bats (Tadarida brasiliensis) at roosts in Texas. Evidence presented showed that fallen bats were a major seasonal food item for Raccoons in the vicinity of the four caves studied. Munson and Keith (1984) demonstrate a long-term predator-prey relationship between Raccoons and Myotis spp. in Wyandotte Cave, Indiana, suggesting a consumption rate of 1150 bats/ year over a period as long as 1500 years.

Although we have occasionally observed Raccoons using bat hibernacula in New Brunswick as winter denning sites (i.e., Markhamville Mine in 2010), we have not previously observed predation on or scavenging of bats overwintering in New Brunswick caves or mines. This is probably because bats, which normally roost high on the ceiling or walls, are not easily accessible to predators in the hibernacula we have visited, and winter mortality of bats is normally low. However, with the onset of WNS in Berryton Cave, the roosting behaviour of bats during the winter changed dramatically, a feature of the disease reported more generally (Foley et al. 2011). Large numbers of bats moved to the front $50 \mathrm{~m}$ of Berryton Cave (in part, to an area near the entrance where winter temperatures dropped below $0^{\circ} \mathrm{C}$ and considerable ice was present). The bats were observed roosting low on the walls, some at floor level. In these areas, dying and dead bats also littered the cave floor. The most significant deposits of Raccoon fæces were found within this first $50 \mathrm{~m}$ of the passage at the cave entrance, suggesting that Raccoon presence in the cave was associated with the availability of food. Scattered piles of isolated wings were likewise found in this area. Bats were also observed flying from the cave into the still snow-covered landscape. Although approximately 50 bat carcasses were recovered outside the cave near the entrance, no signs of scavenging were observed there.

The ratio of pelage to muscle, bone, and viscera is certainly higher in a bat than it is in either Peromyscus or Microtus (probably even when bat wings are not eaten), meaning that when equivalent amounts of wholebody bat and small rodent are consumed, a larger quantity of bat fur and bone than small rodent fur and bone should appear in the fæces. This suggests that the Peromyscus-Microtus coeffiecient of Greenwood (1979) will likely lead to an overestimation of the quantity of bat tissue consumed. However, none of the coefficients for whole vertebrates reported by Greenwood 


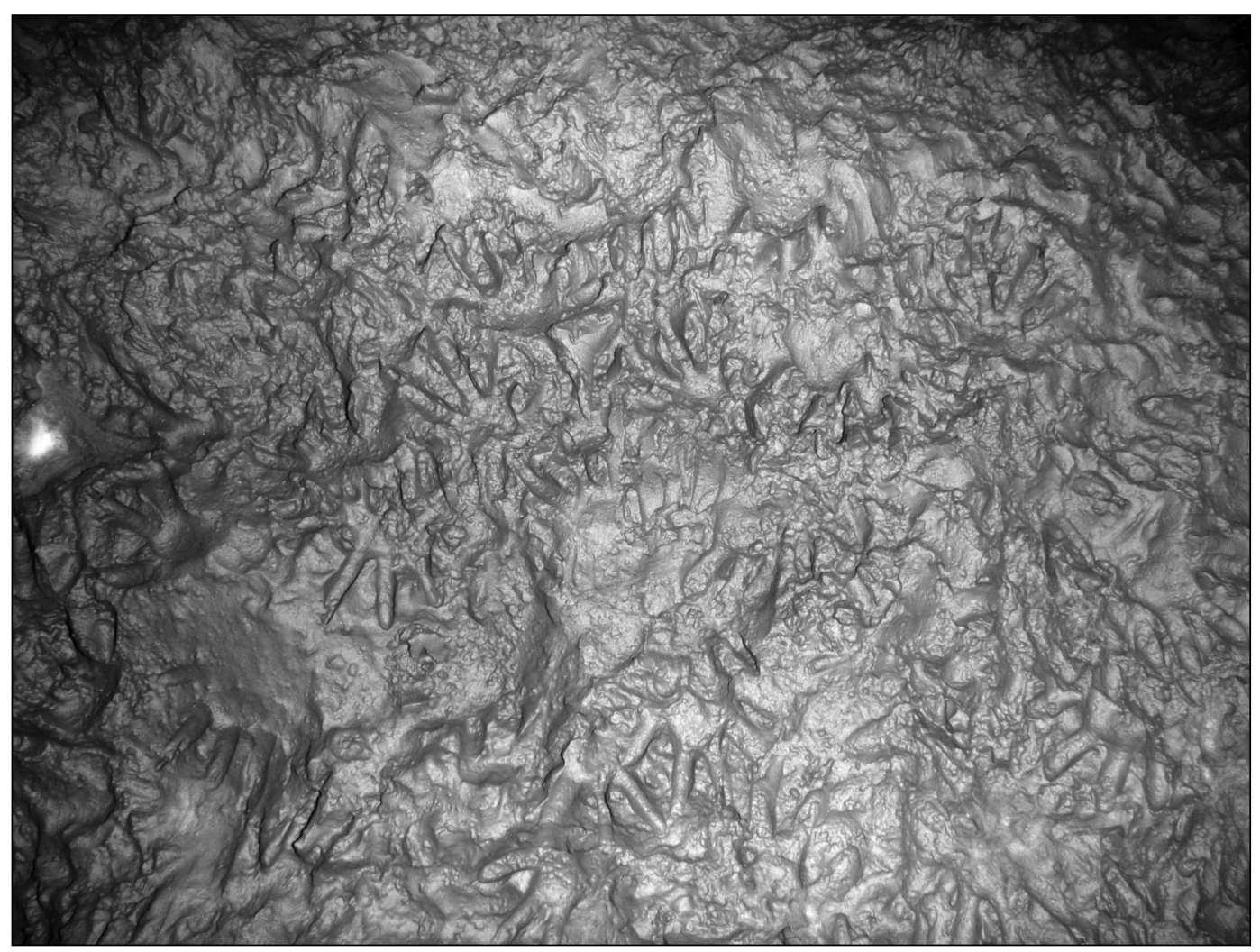

FIGURE 1. Tracks evident on the floor of a passage in Berryton Cave, New Brunswick, in April 2011 suggest much Raccoon activity in the cave following an outbreak of white-nose syndrome in hibernating bats (Myotis lucifugus and M. septentrionalis).

(1979) are below 18.3; even using the lower songbird coefficient to reflect the suggested lower digestibility of bats still indicates a consumption rate of bats infected with WNS by Raccoons in Berryton Cave of $>60 \%$.

Clearly, significant numbers of bats can be removed from hibernacula through Raccoon predation and/or scavenging during WNS outbreaks. Had we not made multiple visits to this site to track the progress of the disease and to count bats, we would likely have significantly underestimated bat mortality. Estimates of incave mortality due to WNS should therefore incorporate any evidence of predation on or scavenging of bats by Raccoons and other predators. Accurate estimates appear to require at least three visits spread across the hibernation period. Although Raccoons do not range widely during winter, it is also possible that not all fæces derived from bats in Berryton Cave were deposited in this cave, so our lower consumption estimates may be conservative.

We determined that Raccoon fæces provide a suitable growth medium for Geomyces destructans in the laboratory. In the cave habitat, however, fast-growing fungi, such as Mucor sp. and Mortierella sp., were prominent on the older fæces and had overgrown (but not necessarily destroyed) slower growing fungi such as Geomyces destructans. Although it has yet to be

TABLE 1. Estimated number of Myotis lucifugus and M. septentrionalis infected with white-nose syndrome consumed by Raccoons in Berryton Cave, New Brunswick, between March and May 2011.

\begin{tabular}{ccccc}
\hline \hline $\begin{array}{c}\text { Faecal } \\
\text { wet } \\
\text { weight }(\mathrm{g})\end{array}$ & $\begin{array}{c}\text { Faecal } \\
\text { dry }\end{array}$ & $\begin{array}{c}\text { Coefficient of } \\
\text { fæcal dry weight } \\
\text { to whole prey }\end{array}$ & $\begin{array}{c}\text { Approximate wet } \\
\text { weight of } \text { Myotis } \\
\text { spp. consumed }(\mathrm{g})\end{array}$ & $\begin{array}{c}\text { Approximate } \\
\text { number of } \text { Myotis } \\
\text { spp. consumed }\end{array}$ \\
\hline 4367.2 & 987.1 & 18.3 (songbird) & 18063.9 & 3169.1 \\
4367.2 & 987.1 & 22.1 (mouse) & 21814.9 & 3827.2 \\
\hline \hline
\end{tabular}

${ }^{1}$ Greenwood (1979)

${ }^{2}$ Based on a mean body weight of $5.7 \mathrm{~g}(\mathrm{SD} \pm 0.82)$ 
determined whether the spores of Geomyces destructans can survive passage through the Raccoon gut, the significant consumption of bats infected by WNS documented here suggests that Raccoons foraging in multiple caves could play a role in transporting Geomyces destructans on their pelage across karst landscapes. Although Raccoons have been observed to move several hundred km (Lotze and Anderson 1979), most Raccoons disperse short distances $(<3 \mathrm{~km})$, with only a small proportion moving distances $>20 \mathrm{~km}$ (Cullingham et al. 2008). In addition, Raccoon activity and movements are reduced during the winter months at northern latitudes (Peterson 1966), where resident bats hibernate and when opportunistic consumption of bats infected by WNS can occur. Although a small number of long-distance Raccoon dispersers could move WNS cave to cave, it would appear that WNS dispersal by Raccoon predators would be important only where bat hibernacula are clustered within $20 \mathrm{~km}$ or less of each other and where Raccoons remain relatively active during the winter months. This would not include eastern Canada or the northeastern U.S., where the Raccoon is near the northern limit of its range (Forbes et al. 2010). Although the means of transmission and spread of WNS are still unknown, bat-to-bat contact remains the most likely avenue.

\section{Acknowledgements}

Funding for our investigations of fungi associated with bats in New Brunswick was provided by the New Brunswick Wildlife Trust Fund, the New Brunswick Department of Natural Resources, and the Canadian Wildlife Federation through an Orville Erickson Scholarship to K. J. V. Confirmation of WNS at Berryton Cave was made through the Canadian Cooperative Wildlife Health Centre and the assistance of Dr. Scott McBurney, Atlantic Veterinary College, University of Prince Edward Island. We thank Tony Gilchrist, who owns the land on which the Berryton Cave entrance is situated, for both his interest in bat conservation and his cooperation in allowing us entry to the site.

Documents Cited (marked * in text)

New Brunswick. 2011. White-nose syndrome. http://www2 .gnb.ca/content/dam/gnb/Departments/nr-rn/pdf/en/Wildlife /Bats-WhiteNoseSyndrome.pdf.

U.S. Fish and Wildlife Service. 2011. White-nose Syndrome. http://www.fws.gov/whitenosesyndrome. (Accessed 21 June 2011).

\section{Literature Cited}

Arsenault, S. P., J. Schroeder, D. Bérubé, and R. Albert. 1997. The caves of southeastern New Brunswick (revised and supplemented). New Brunswick Department of Natural Resources and Energy Open File 97-7. 33 pages.

Blehert, D. S., A. C. Hicks, M. Behr, C. U. Meteyer, B. M. Berlowski-Zeir, E. L. Buckles, J. T. Coleman, S. R. Darling, A. Gargas, R. Niver, J. C. Okoniewski, R. J. Rudd, and W. B. Stone. 2009. Bat white-nose syndrome: an emerging fungal pathogen? Science 323: 227.

Cryan, P. M., C. U. Meteyer, J. G. Boyles, and D. S. Blehert. 2010. Wing pathology of white-nose syndrome in bats suggests life-threatening disruption of physiology. BMC Biology 8: 135. (Available at http://www.biomedcentral.com/ 1741-7007/8/135).

Cullingham, C. I., B. A. Pond, C. J. Kyle, E. E. Rees, R. C. Rosatte, and B. N. White. 2008. Combining direct and indirect genetic methods to estimate dispersal for informing wildlife disease management decisions. Molecular Ecology 17: 4874-4886.

Foley, J., D. Clifford, K. Castle, P. Cryan, and R. S. Ostfeld. 2011. Investigating and managing the rapid emergence of white-nose syndrome, a novel, fatal, infectious disease of hibernating bats. Conservation Biology 25: 223231.

Forbes, G. J., D. F. McAlpine, and F. W. Scott. 2010. Mammals of the Atlantic Maritime Ecozone. Pages 693-718 in Assessment of Species Diversity in the Atlantic Maritime Ecozone. Edited by D. F. McAlpine and I. M. Smith. NRC Research Press, National Research Council Canada, Ottawa, Ontario.

Greenwood, R. J. 1979. Relating residue in raccoon feces to food consumed. American Midland Naturalist 102: 191193.

Lorch, J. M., C. U. Meteyer, M. J. Behr, J. G. Boyles, P. M. Cryan, A. C. Hicks, A. E. Ballmann, J. T. H. Coleman, D. N. Redell, A. M. Reeder, and D. S. Blehert. 2011. Experimental infection of bats with Geomyces destructans causes white-nose syndrome. Nature 480: 376-378. doi: 10.1038/nature 10590. http://www.nature.com/nature/jour nal/v480/n7377/full/nature10590.html.

Lotze, J.-H., and S. Anderson. 1979. Procyon lotor. Mammalian Species 119. American Society of Mammalogists.

Munson, P. J., and J. H. Keith. 1984. Prehistoric raccoon predation on hibernating Myotis, Wyandotte Cave, Indiana. Journal of Mammalogy 65: 152-155.

Papavizas, G. C., and C. B. Davey. 1958. Evaluation of various media and antimicrobial agents for isolation of soil fungi. Soil Science 88: 112-117.

Peterson, R. L. 1966. The Mammals of eastern Canada. Oxford University Press, Toronto.

Winkler, W. G., and D. B. Adams. 1972. Utilization of southwestern bat caves by terrestrial carnivores. American Midland Naturalist 87: 191-200.

Received 11 November 2011

Accepted 18 December 2011 